\title{
OROGENIC HIGH-PRESSURE PERIDOTITES OF KAN TERRANE - POSSIBLE SOURCE OF DIAMONDS FOR ALLUVIUM OF THE SOUTH PART OF THE SIBERIAN PLATFORM (RUSSIA)
}

\author{
MIKHAIL TSYPUKOV ${ }^{1}$
}

\begin{abstract}
High-pressure garnet lherzoliths were found recently in the Igil massif of the Early Precambrian Kan terrane, Siberian platform basement. Peridotites reveal multistage evolution and had high-temperature spinel protolith $(1040-1123,<20 \mathrm{~kb})$. At the first stage of the evolution these rocks were moved isobarically to the garnet stability field $\left(860^{\circ} \mathrm{C}-20 \mathrm{~kb}\right)$. At the second stage garnet-spinel peridotite sank to a deeper and hotter mantle level $\left(933-977^{\circ} \mathrm{C}-25 \mathrm{~kb}\right)$. The main deformation accompanied the latest progressive metamorphism was in the garnet stability field. Garnet peridotites underwent regressive metamorphism and were exhumed afterwards. Stages of the evolution reflect definite plate-tectonic events, which were caused by continental collision and subduction. At the first stage mantle wedge spinel peridotites were thrust to the sinking cold continental block as a consequence of collision and subduction. These rocks sank together with continental crust to the deeper level of upper mantle. Next stages were connected with regressive metamorphic events during the exhumation of Kan terrane. Presence of HP garnet ultramafites suggest the Kan Precambrian block to be a source of diamonds and pyropes in the alluvium of the Siberian platform south part.
\end{abstract}

Keywords: garnet peridotite, orogenic peridotite, high-pressure metamorphism, geothermobarometry; high-pressure terrane.

\begin{abstract}
INTRODUCTION High-pressure orogenic mantle ultramafites are common attribute of high-pressure - ultrahigh pressure (HP-UHP) terranes. Such terranes have been described in Europe (Western Gneiss Region of Norway, Bohemian Massif of Czech Republic etc.) and China (Su-Lu and Dabie). These rocks are a key to understanding upper mantle composition and processes. They are of the keen and constant interest of petrologists not only due to their unclear origin, but also their possible diamond potential, which was identified after the discovery of graphite pseudomorphs replacing diamond in the Beni Bouchera Massif, Morocco (Slodkevich 1982, Dobrzhinetskaya et al. 1995). According to the latest research orogenic garnet-bearing peridotites might be exhumed from mantle depth of diamond stability field. Ultradeep origin ( $>6 \mathrm{Gpa}$ ) for Otroy peridotites (WGR) was assumed (Van Roermund et al. 2000). Occurrences of high-pressure ultramafites were recently found in the Kan Early Precambrian terrane, which is considered as a basement of the Siberian platform (Tsypukov \& Kostrovitski 1999). Over an area of about 600 sq.km, a total number of 400 ultramafic bodies are present. Moreover the presence of diamonds and pyropes in alluvium of the southern Siberian platform has been known for decades. This fact suggests that the Kan HP orogenic peridotites are a possible source of the high-pressure minerals in the neighboring alluvium.
\end{abstract}

GEOLOGICAL SETTING The Kan terrane is supposed to be a collisional orogen (Tsypukov 2001). There are three main metamorphic units of different composition distinguished inside the area. Paragneisses after graywackles, metapelites and quartzites are dominant in the eastern part of terrane.
Metamorphosed leicocratic basalt-andesite-rhyodacite series and melanocratic picrite-basalt series prevail in the central and western part of terrane. Plutonic complexes composed of pyroxenite, anorthosite, and gabbro intrude theses amphibolitegneisses suites. All of the lithological and magmatic units have experienced multiple phases of intense deformation. Mineral assemblages are indicative of amphibolite and epidoteamphibolite facies metamorphism at moderate to elevated pressures. $\mathrm{K} / \mathrm{Ar}$ and $\mathrm{Rb} / \mathrm{Sr}$ ages clearly indicate a Late Archean age (2.8-2.7 Ga) for metavolcanic units and $3260 \pm 50 \mathrm{Ma}$ for the basement complex (Romanov \& Gerasimov 1987). Various granitoids from the Kan terrane have reported $\mathrm{Pb} / \mathrm{Pb}$ zircon and allanite ages of $1900 \pm 65,1830 \pm 25$ and $1750 \pm 340 \mathrm{Ma}$ (Volobuev et al. 1980).

The Kan terrane is a province of high-pressure ultramafites of mantle origin. Usually these rocks occur concordant as boudins and lenses (0.5-20 $\mathrm{m}$ in thickness) in para- and ortometamorphic suites. Peridotites of small massifs usually comprise serpentinites after dunites, harzburgites and lherzolites. The latter contain spinel-cpx-chlorite intergrowths, pseudomorphic after garnet. The largest of the ultramafic massifs is the Igil massif. This lenticular ultramafic body is 1.8 $\mathrm{km}$ long and $400 \mathrm{~m}$ wide. The observed layering and schistosity dip gently to the east and steeply to southwest respectively. The massif is mainly composed of spinel facies dunite, harzburgite and lherzolite. The lherzolite consists of olivine (50-70 vol. \%), clinopyroxene (12-15\%), orthopyroxene $(10-12 \%)$, spinel $(0-7 \%)$, garnet (0-20\%), amphibole $(<3 \%)$ and serpentine $(0-10 \%)$. Garnet peridotites are scarce and observed only in small exposures, a few meters in width. The serpentinization of ultramafics is extensively developed. 
The serpentine commonly inherits the ocellar-banded structure of the lherzolites. The rocks typically exhibit deformation and recrystallization structures. The porphyroclastic textures are especially typical of harzburgite and lherzolite. In garnet Iherzolites of Igil massif the porphyroblasts and neoblasts of olivine and pyroxene, as well as the garnet porphyroblasts are incorporated into a fine-gained neoblastic groundmass of crushed and subsequently recrystallized olivine.

MINERAL CHEMISTRY The garnet lherzolites are characterized by an anomalously high proportion of chemically unequilibrated samples. They demonstrate variable mineral compositions and, hence, a wide range of calculated thermodynamic crystallization conditions. Six generation of $\mathrm{cpx}$, four of opx and two of garnet were recognized in garnet lherzolithes according to petrographical data. Different generations slightly differ chemically mostly in $\mathrm{Al}, \mathrm{Cr}, \mathrm{Ca}$ (pyroxenes) or $\mathrm{Cr}, \mathrm{Fe}$ (garnets) as a consequence of forming conditions. The olivine is characterized by low $\mathrm{Cr}$ and $\mathrm{Ca}$ contents $(<0.1 \mathrm{wt} \%)$ and a high $\mathrm{NiO}(0.4-0.5 \mathrm{wt} \%)$. $\mathrm{Mg \#}$ varies from 88 to 95 (average 90,67 ), and is proportional to the $\mathrm{Mg} \#$ of the host rock. $\mathrm{Mg \#}$ in orthopyroxene (enstatite) varies within the same limits. The $\mathrm{Al}_{2} \mathrm{O}_{3}$ content of orthopyroxene ranges from 1.5 to $6.5 \mathrm{wt} \%, \mathrm{Cr}_{2}^{2} \mathrm{O}_{3} 0.1-0.7 \mathrm{wt} \%, \mathrm{CaO} 0.15$ $1.8 \mathrm{wt} \%$. The clinopyroxene (diopside) is close to $\mathrm{Cr}$-diopside (0.4-1.3 wt \% $\left.\mathrm{Cr}_{2} \mathrm{O}_{3}\right)$, its $\mathrm{Fe}$ index is $5.9-9.5 \%$. The relative amount of the high-pressure jadeite component is rather high (4.9-12.5 mol \%). The $\mathrm{Al}_{2} \mathrm{O}_{3}$ contents in cpx vary from 5.2 to 8.8 wt \%, $\mathrm{Na}_{2} \mathrm{O} 0.5-2.1^{2}$ wi \%. Both $\mathrm{Cpx}$ and $\mathrm{Opx}$ have a regressive diffusion zoning in the rim of grains. Sharp decreasing of $\mathrm{Al}, \mathrm{Na}, \mathrm{Cr}$ and increasing of $\mathrm{Mg}$ and $\mathrm{Si}$ could be seen in margins. Both pyroxenes have pyroxene or pyroxenespinel exsolution lamellaes.

The pyralspitic garnet contains up to $76 \mathrm{~mol} \%$ of pyrope. The regressive diffusive zoning in garnet grains is expressed in the increase of $\mathrm{Fe}$ and $\mathrm{Mn}$ contents in the margins of grains. Simultaneously, the pyrope component is depleted to 63-67 mol \%. Based on all parameters, except the low $\mathrm{Cr}_{2} \mathrm{O}_{3}$ content (0.1-1.5 wt \%), the garnet compositions are consistent with equilibration with a Iherzolite assemblage. Garnet has opx or opx-rutile, or opx-amph-rutile exsolution lamellaes and isometric mineral inclusions of cpx and $\mathrm{spn}\left(\mathrm{Al}_{2} \mathrm{O}_{3} 49-53 \mathrm{wt}\right.$ $\%)$.

ROCK CHEMISTRY Orogenic peridotites and dunites have clear chemical evidence of formation from the mantle as residues after basalt melt removal. The degree of melting is calculated to vary from 7 to $17 \%$ (Gornova et al. 2001). In comparison with primitive mantle (PM) these peridotites have lower contents of highly and moderately incompatible elements (Fig. 1). Lherzolites, the most fertile rocks observed in the terrane, demonstrate slight depletion of high incompatible elements (figl), that could indicate a smaller degree of melting. Peridotites have high abundances of $\mathrm{Al}, \mathrm{Sr}, \mathrm{Ba}, \mathrm{Rb}$, which may be related to substantial amounts of phlogopite being introduced as a consequence of metasomatism or granitization.

\section{GEOTHERMOBAROMETRY AND P-T PATH OF} GARNET LHERZOLITHES There are few lines of mineralogical evidence constraining the major processes responsible for the formation and PT evolution of these rocks. The P-T estimates based on the geothermobarometry yield a substantial scatter due to the complex evolution of the rock, the lack of a common equilibrium mineral assemblage. The following geothermobarometers were used for the PT callculation: two-pyroxene and Ca-in-opx (Brey \& Kohler 1990), garnet-clinopyroxene (Krogh 1988) geothermometers, garnet-opthopyroxene (McGregor 1974) geobarometer.

There are evidence of local equilibrium in these rocks, like exsolution lamellaes and mineral inclusions. Spinel inclusions in garnet infer the spinel facies protolth. Opx porphiroclasts correspond to the early spinel stage and were formed in hightemperature $\left(1040-1123^{\circ} \mathrm{C}\right)$ conditions because of high $\mathrm{CaO}$

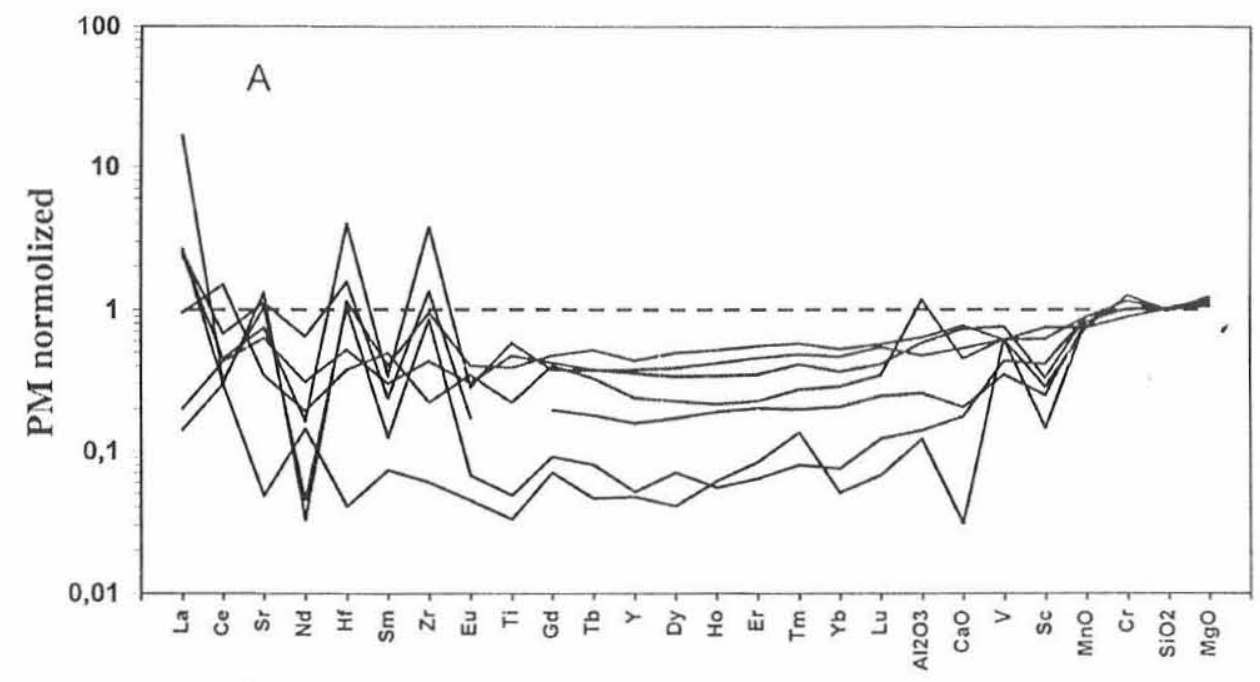

Figure I - PM normalized (after McDonough, Sun 1995) contents of major and minor elements in mantle orogenic peridotites of Kan terrane. 
Table I-Stages of metamorphic evolution of garnet lherzolithes of the Kan terrane.

\begin{tabular}{|c|l|l|l|}
\hline & Stage & $\mathrm{T}\left({ }^{\circ} \mathrm{C}\right)$ & $\mathrm{P}(\mathrm{kb})$ \\
\hline 1 & High-lem perature spinel facies protolith & $1040-1123$ & 20 \\
\hline 2 & Isobaric Transition to the garnet stability field & $857-877$ & 20 \\
\hline 3 & Deformation stage & $933-977$ & $24-25$ \\
\hline 4 & Regression stage I & $863-818$ & $24.2-17.5$ \\
\hline 5 & Granulutic stage & $722-781$ & 14 \\
\hline 6 & Regression stage II & 657 & $<14$ \\
\hline
\end{tabular}

contents (up to $1.8 \mathrm{wt} \%$ ). According to $\mathrm{Al}$-in-opx geobarometer spinel facie pressure was about $20 \mathrm{~kb}$ (Table 1). The next imprinted stage, is an isobaric transition from spinel to garnet stability field because of $\mathrm{T}$ decrease. Garnet $\mathrm{I}\left(\mathrm{Cr}_{2} \mathrm{O}_{3}\right.$ $=1.08 \mathrm{wt} \%, \mathrm{FeO}_{\text {tot }}=11.95 \mathrm{wt} \%$ ) has no zoning and was captured in to the cpx crystal as poikilocrystal and keep early garnet stage conditions of 857-877 C. The big porphiroblastic garnet (garnet II) have more $\mathrm{Cr}$ and less $\mathrm{Fe}$ contents $\left(\mathrm{Cr}_{2} \mathrm{O}_{3}=\right.$ $1.56 \mathrm{wt} \%$, and $\mathrm{FeO}_{\text {tot }}=9.65 \mathrm{wt} \%$ ) that may point to the higher pressure of formation (23-25 kb), than the garnet I. Deformation was developed in lherzolithes mostly in garnet stability field and were connected with peak pressure of $25 \mathrm{~kb}$ and $\mathrm{T}=933-977{ }^{\circ} \mathrm{C}$. Opx exsolution lamelaes in garnet II shows drop of $\mathrm{P}$ from 25 to $17 \mathrm{~kb}$ and $\mathrm{T}$ down to $818^{\circ} \mathrm{C}$ what reflect the exhumation of the terrane.

DISCUSSION AND CONCLUSION Modeling of the compositions of the Kan peridotites suggests that these originated as residues of melting of the Primitive Mantle. Two models were checked to explain their origin - fractional and incremental $(0.1 \%$ increments) melting models. The latter displays better correlation with the real data. According to these data, the peridotites were formed as a result of $3-15 \%$ melting of PM not in garnet, but in spinel facies. The complementary melt would be of basaltic composition (EMORB) and may correspond to the amphibolites of the northeast part of Kan terrain. In spinel facies, peridotites melt according the equation

$$
\mathrm{Cpx}+\mathrm{Opx}+\mathrm{Sp} \pm \mathrm{Mg}-\mathrm{Ol}+\mathrm{Cr}-\mathrm{Sp}+\mathrm{L} .
$$

This is observed in the Kan peridotites, where increasing $\mathrm{MgO}$ is accompanied by increasing $\mathrm{Mg} \#$ in $\mathrm{Ol}$ and $\mathrm{Cr} \#$ in spinel. Spinel compositions fall within the field of abyssal peridotites, which were formed under mid-ocean ridges.

The presence of mantle garnet lherzolites and spinel lherzolites and harzburgites in an amphibolite-gneiss complex indicates that the Kan metamorphic block is a high-pressure terrane, which was subducted to a mantle depth of $100 \mathrm{~km}$ or more. Geological evidence shows such massifs to be the fragments of thin mantle lenses generated as a consequence of underthrusting. The high extent of alteration of the ultramafites indicates that they represent the mantle wedge above the subducted slab.

PT path of garnet therzolithes may be explained from the positions of platetectonics. High-temperature spinel protholith in the form of lenses or plates was thrust to the cold subducted continental block and sank to the deeper levels of the mantle. During the peak metamorphism (25 kb, 933-977 C) rocks were deformed and acquired sheared fabrics. The opx exsolutions in garnet, garnet $\mathrm{Fe}-\mathrm{Mg}$ retrograde diffusive zonation pattern and pyroxene and spinel exsolution structures in pyroxenes retained information on the reduction of pressure (25-13 kb) and temperature (980-670 o ) through this retrograde stage. There are differences in chemical composition of minerals of garnet lherzolith as well. Pyroxenes which were formed in garnet facies have more $\mathrm{Cr}$ and less $\mathrm{Al}$ contents, than minerals formed in spinel facies. Garnet of the earliest stages is more ferric and have less $\mathrm{Cr}$, than the one, formed in high-pressure conditions. There is no evidence of HP-UHP metamorphism in the Kan terrane besides the presence of garnet peridotites. However, these provide every reason to believe that other highpressure assemblages were present in the Kan terrane as well, but were obliterated by retrograde metamorphism. The presence of diamonds in alluvium in the southern part of the Siberian platform has been known for decades and the source of diamonds remains unclear. In this respect, the HP peridotites of Kan terrane could be considered as a potential source.

Acknowledgements This work was supported by the Russian Foundation for Basic Research, project no 96-05-64945. To two anonymous referees of RBG for suggestions to the manuscript.

\section{References}

Dobrzhinetskaya L.F. 1995 Microdiamonds in high-grade metamorphic rocks of the Western Gneiss Region, Norway. Geology, 23:597-60).

Gornova M.A., Tsypukov M.Yu., Sandimirova G. P.. Smirnova V. 20()1. Melting of Precambrian mantle: geochemical analysis of residual orogenic peridotites of the Siberian craton periphery. Doklady RAS, 378:383-386 (in Russian).

McDonough W.F. \& Sun S.-S. 1995. The composition of the Earth. Chemical Geology, 120:223-253. 
Romanov I.A. \& Gerasimov N.S. 1987. Rb/Sr dating of the Precambrian Malotagul deposit (Eastern Sayan). In: F.A. Letnikov (Ed.) Geology, Ore Deposits and Geochronology of the Precambrian in the Siberian Platform and Surrounding Areas. Inst. Earth Crust Publ., Irkutsk, pp. 226-227 (in Russian).

Slodkevich V.V. 1982. Zap. Vseross. Mineral. Obshestva, no. I, part. III, pp. 1333 (in Russian).

Tsypukov M.Yu. \& Kostrovitsky S.I. 1999. The mantle nature of ultramafic rocks of the Igil massif, The Kan Block. Doklady Akademii Nauk, 364(5):671674 (in Russian).
Volobuev M.I., Zykov S.I., Stupnikova N.1. 1980. Pb isotope geochronology of Precambrian metamorphic complexes along the southwestern margin of the Siberian Platform. In; Geochronology of Eastern Siberia and the Far East. Nauka Press, Moscow, pp. 14-30 (in Russian).

Van Roermund H.L.M., Drury M.R., Barnhoorn A., De Ronde A.A. 2000 Supersilicic garnet microstructures from an orogenic garnet peridotite, evidence for an ultra-deep (>6 GPa) origin. J. Metamorphic Geol., 18:135-147

Manuscrito A-1297

Recebido em 21 de novembro de 2001

Revisão do autor em 12 de dezembro de 2001 Revisão aceita em 13 de dezembro de 2001 